Krzysztof Duda

Akademia Ignatianum w Krakowie

\title{
Przyczynek do historii nauki i kultury polskiej, czyli o odnalezionych archiwaliach Józefa Rostafińskiego (1850-1928)
}

W 1893 r. w Krakowie opublikowane zostało dzieło dotyczące kultury ludowej, naukowo prezentujące jej przyrodniczo-religijny aspekt. Praca nosiła tytuł Zielnik czarodziejski. Tojest zbiór przesąów o roślinach ${ }^{1}$ a jej autorem był prof. Józef Rostafiński². W opublikowanej książce ten wybitny uczony dalece wykraczał poza badania przyrodnicze, którymi się zajmował. Podjęty przez niego temat wchodził bowiem w obszar nauk historycznych i nauk o kulturze ludowej, które w tym czasie nazywano ludoznawstwem. Badania Rostafińskiego były zatem pionierskie nie tylko na polu przyrodniczym, ale i w obszarze nauk o człowieku³. Dwa lata później - w 1895 r. - Akademia Umiejętności zamieściła publikację Rostafińskiego właśnie w dziale etnologicznym; w tomie XVIII „Zbioru Wiadomości do Antropologii Krajowej"4.

Aby przygotować się do publikacji dotyczącej roślin, które polski lud - zamieszkujący obszar trzech zaborów - stosował w swoim życiu

1. J. Rostafiński, Zielnik czarodziejski. To jest zbiór przesądów o roślinach, Kraków 1893 i n.

2. Józef Rostafiński (1850-1928), polski profesor, botanik, historyk nauk przyrodniczych. Zob. H. Bukowiecki, Rostafiński Józef Tomasz (1850-1928), w: Słownik biologów polskich, Warszawa 1987, red. S. Feliksiak, s. 453-454.

3. Zob. A. Zemanek, Koleje życia Józefa Rostafińskiego, w: Józef Rostafiński. Botanik i humanista, red. A. Zemanek, Kraków 2000, s. 19-106.

4. J. Rostafiński, Zielnik czarodziejski, "Zbiór Wiadomości do Antropologii Krajowej", XVIII (1895) cz. 3, s. 1-191. 
i nadawał im znaczenie religijne, magiczne i użytkowe, Rostafiński wystosował w 1883 r. Odezwę ${ }^{5}$. Skierował ją do ziemian, duchownych, nauczycieli, lekarzy i aptekarzy, prosząc o odpowiedź, która ułatwi mu opracowanie materiału ${ }^{6}$. Po jej wielokrotnej publikacji w prasie do Rostafińskiego spłynęło ponad tysiąc odpowiedzi. To one - poza studiami archiwalnymi, które prowadził ów badacz - doprowadziły do powstania Zielnika. Książka doczekała się kilku wydań, jednak same rękopisy odpowiedzi osób ankietowanych są mało znane. Duża ich część - znajdująca się w zasobach Instytutu Botaniki Uniwersytetu Jagiellońskiego w Krakowie - jest systematyczne opracowywana przez Piotra Köhlera. Jednak kolekcja ta jest niepełna. Spora część listów została uznana za zaginioną i przez kilkadziesiąt lat środowisko naukowe nie miało o niej żadnych informacji.

Celem artykułu jest właśnie skrótowa prezentacja wybranych elementów odnalezionej w 2014 r. części zbioru określonego przez Rostafińskiego jako „Królestwo", w którym znajdują się odpowiedzi na wspomnianą już Odezwę. W odnalezionych materiałach znajdują się również osobiste notatki Rostafińskiego, a także korespondencja, którą otrzymywał od innych uczonych. Artykuł ma na celu jedynie zasygnalizowanie istnienia tego zbioru, zaś prezentacja całości odnalezionych archiwaliów będzie przedmiotem pracy, którą autor planuje podjąć w przyszłości. W jego zamyśle jest bowiem przygotowanie edycji rękopisów listów oraz ich krytyczne opracowanie. Podjęcie takiej pracy wydaje się zasadne ze względu na znaczenie tego materiału dla historii kultury, historii nauk rolniczych i przyrodniczych oraz antropologii kulturowej.

\section{Odnaleziony zbiór Rostafińskiego}

Zbiór dokumentacji Rostafińskiego został zachowany przez wybitnego znawcę flory Karpat Wschodnich - ucznia prof. Mariana Raciborskiego ${ }^{7}-$

5. Zob. P. Köhler, Ankieta Józefa Rostafińskiego z 1883 roku dotycząca ludowego i użytkowania roślin w Polsce, „Analecta - Studia i Materiały z Dziejów Nauki" 6 (2016), s. 87-119; zob. też: P. Köhler, Rośliny święcone w ankiecie Józefa Rostafińskiego (1850-1928) z 1883 r., "Etnobiologia Polska" 6 (2016), s. 129-190.

6. $\quad$ APA, J. Rostafiński, Odezwa do nie botaników o zbieranie ludowych nazw roślin (wyd. IV), mps, Kraków 1883.

7. Marian Raciborski (1863-1917), polski profesor, botanik, pionier prac z zakresu ochrony przyrody jako dobra kulturowego ludzkości. Zob. H. Bukowiecki, Raciborski Marian (1863-1917), w: Słownik biologów polskich, red. S. Feliksiak, Warszawa 1987 , s. $441-443$. 
prof. Tadeusza Wilczyńskiego ${ }^{8}$. Wilczyński, pracujący na Uniwersytecie Jana Kazimierza, po wojnie pozostał we Lwowie i tam też zmarł w 1981 r. Dopiero po jego śmierci zbiory, które gromadził przez lata, zgodnie z jego ostatnią wolą - w nieznacznej części - trafiły do Polski. Kolekcję zielników otrzymała Polska Akademia Nauk w Krakowie, materiały rękopiśmienne, książki i osobiste notatki trafiły do jego rodziny. Natomiast najbardziej znaczące dla kultury polskiej obiekty (tj.: kolekcja obrazów, grafik, medali, medalionów i plakiet) pozostały we Lwowie, gdzie nieudostępniane znajdują się we Lwowskiej Galerii Sztuki im. Borysa Woźnickiego9.

O ile zbiory botaniczne przekazane PAN w Krakowie są dostępne i zapewne będą systematycznie opracowywane, o tyle zbiór przekazany rodzinie nie był znany i dopiero wyzbycie się go przez nią pozwoliło w znacznym stopniu uzyskać ogląd tego, co pozostało po Wilczyńskim. Niestety sprzedaż również rozdrobniła zbiór i nie wiadomo, czy kiedykolwiek uda się dotrzeć do posiadaczy poszczególnych elementów jego kolekcji. Wśród dostępnych materiałów piśmienniczych zostały

8. Tadeusz Wilczyński (1888-1981), polski profesor, botanik, florysta i kolekcjoner. Odbudowywał zniszczoną w czasie I wojny światowej stację wysokogórską na Połoninie Pożyżewskiej. Następnie utworzył we Lwowie Ogród Roślin Lekarskich. Wykładał na Politechnice Lwowskiej oraz Uniwersytecie Jana Kazimierza. Po II wojnie światowej został we Lwowie jako profesor farmakognozji we Lwowskim Instytucie Medycznym oraz kierownik Ogrodu Roślin Leczniczych. Zmarł w zapomnieniu. Pozostawił po sobie kilkudziesięciotysięczny zbiór okazów botanicznych oraz zbiory antyków, znajdujące się obecnie we Lwowie. Był też fotografikiem, który pozostawił spore zbiory zdjęć obrazujące głównie Karpaty Wschodnie. Został pochowany na Cmentarzu Łyczakowskim. Zob. K. Duda, Tadeusz Wilczynski (1888-1981) and Josef Treshka (19o6-1945): images of the forgotten world, w: „Вісник Кам'янець-Подільського національного університету імені Івана Огієнка: Історичні науки" 2016 nr 9, s. 406-417.

9. A. Gordijewska, Prezentacja Katalogu polskich medalionów i medali we Lwowie, "Kurier Galicyjski" 2016 nr 4 (248), s. 12.

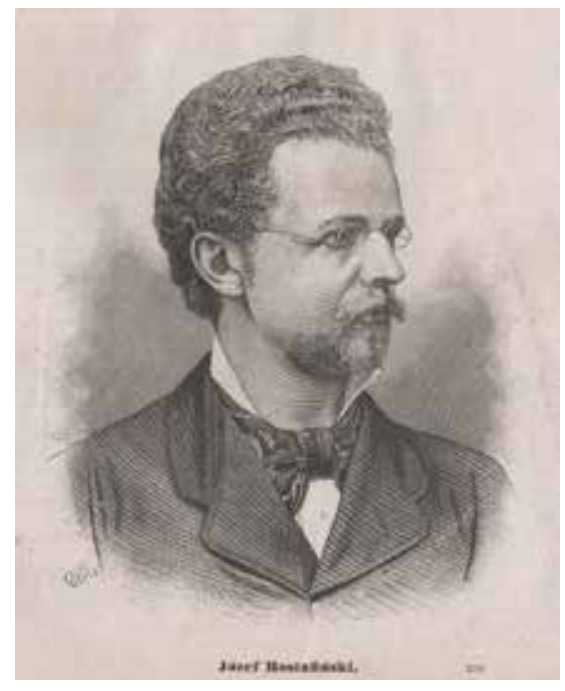

1. A. Regulski, Józef Rostafiński (1850-1925). Drzeworyt sztorcowy ${ }^{\mathrm{a}}$, archiwum prywatne autora $^{\mathrm{b}}$

a. Drzeworyt zamieszczony w "Tygodniku Ilustrowanym", nr 145, 5 X 1887, s. 209, autorstwa Aleksandra Regulskiego (1839-1884), polskiego drzeworytnika. Zob. W. Rukóyżo, Regulski Aleksander Tadeusz (1839-1884), w: Polski Słownik Biograficzny, t. 30, Wrocław 1987, s. 739 .

b. Dalej APA. 


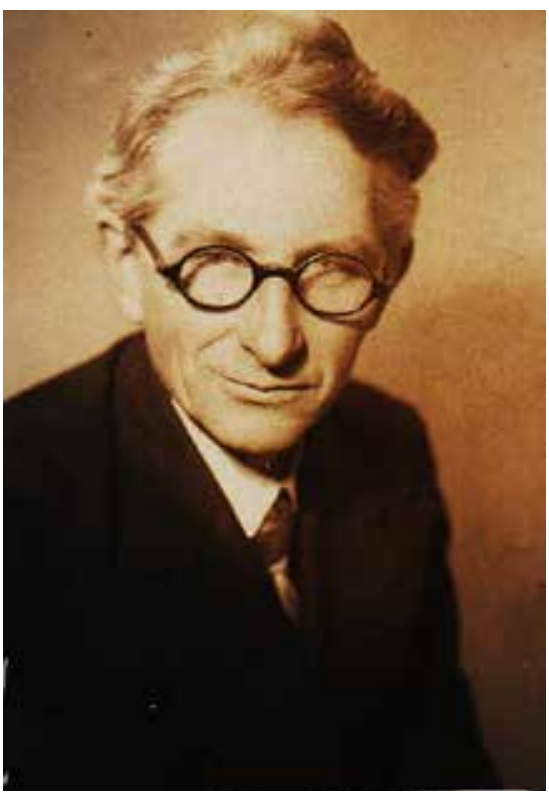

2. Prof. Tadeusz Wilczyński (1888-1981), APA odnalezione właśnie materiały archiwalne Józefa Rostafińskiego. Nie wiemy, w jaki sposób znalazły się one w posiadaniu Wilczyńskiego, możemy jednak przypuszczać, że po zawirowaniach związanych z pozostaniem Lwowa w granicach ZSRR, a także pozostaniem tam samego profesora, zbiór, który trafił do jego rąk, został też tam przez niego przechowany.

\section{Zawartość odnalezionego zbioru}

W kolekcji rękopiśmiennej Rostafińskiego, zachowanej przez Wilczyńskiego, znajduje się wspomniana już Odezwa, która jest wydaniem czwartym, dokonanym nakładem autora w drukarni „Czasu" w Krakowie. Jeśli zaś chodzi o pozostałe dokumenty znajdujące się w składce "Królestwo", to liczą one 270 odręcznie zapisanych stronic różnego formatu. Liczba dokumentów z 1873 r. wynosi 49, w tym jedna zadrukowana karta wizytowa, na której znajdują się również zapiski Rostafińskiego. Z tego roku pochodzi też list jednego ze studentów Rostafińskiego, w którym zachęca pozostałych uczniów profesora do rozpowszechniania Odezwy wraz z adresami osób mogących udzielić odpowiedzi na zawarte w niej pytania. Do roku 1873 można też przypisać sześć sztuk spisów abonentów Odezwy. Z roku 1874 pochodzi 26 dokumentów, w tym jedna koperta. Jeden dokument jest z roku 1883, dwa z 1885 r., z zaś z 1887 r. dziewięć dokumentów. Całość zbioru domykają dwa jednokartkowe brudnopisy sporządzone ręką Rostafińskiego. Są to spisy treści przygotowywanej przez niego publikacji o roślinach użytkowanych przez lud. Każdy z nich jest datowany na 13 stycznia 1888 r. Listy przychodzące w latach 1873-1874 mają potrójną numerację, trudno określić, czy jest ona autorstwa Rostafińskiego.

\section{Treść Odezwy}

W Odezwie, która składa się z 70 pytań, Rostafiński zwraca się z prośbą, zwłaszcza do „wiekowych ludzi, którzy z tradycji pamiętają niebywałe już rzeczy, aby 
raczyli pomó ${ }^{10}$ mi swą wiedzą" ${ }^{11}$. Dalej podaje sposób, w jaki należy szukać odpowiedzi na postawione przez niego pytania. Pisze, że jest on „bardzo prosty. Dość wezwać starszą jaką kobietę, zwłaszcza taką, która we wsi jest znana z tego, że zna i zbiera zioła i wypytać ją w porządku «Odezwy», stawiając pytania "Odezwy», nieraz kilkakrotnie, w coraz różnej formie, bo może pierwsze nie od razu będzie zrozumiałe, następnie zaś po upływie pewnego czasu dopełniać innych. Dopytywać się nawet kilkakrotnie, bo zwykle ostatnie krople mleka są najtłustsze. Przy tym ${ }^{12}$ zaznaczam, że pragnąłbym mieć nazwy roślin podane we właściwym ${ }^{13}$ ludowym $^{14}$ brzmieniu nie przemienione na piśmienny język, bo o nie najwięcej mi chodzi"15. Tak obrana metodologia miała dać Rostafińskiemu najbardziej źródłowy materiał, tak z punktu widzenia historycznego, jak i kulturowego, co z pewnością było najlepiej obraną perspektywą badawczą.

Najciekawsze - z punktu widzenia obrzędowości i znaczenia dla powstania Zielnika - były pytania dotyczące tego, w jakim - poza użytecznym celu lud zbiera zioła. Rostafińskiemu chodziło w tym pytaniu o to, by dowiedzieć się, jaki związek ma zielarstwo z religią, a także czy zioła i jeśli tak, to które - mają znaczenie magiczne. W pytaniu 62 krakowski uczony prosi o odpowiedź na pytanie: „Jakie zioła zbiera lud na wianeczki poświęcane na Boże Ciało? Jakie wsadza w strzechę w wilię ${ }^{16}$ św. Jana lub Zielone Świątki? Do czego tych ziół używa?"17 Dopełnia ten temat w następnych pytaniach. I tak, w pytaniu 63 chodzi mu o wyjaśnienie: „Jakie zioła zbiera lud na tak zwane ziele, które się święci 15 sierpnia? Wypisać wszystkie i dowiedzieć się, czy lud zbiera je na miedzach, i czy ma np. zwyczaj zbierać je na 7 czy 9 miedzach. Do czego tych ziół używa?". Kolejne pytania brzmią następująco: "64) Jakie zioła używa lud na lek dla siebie? 65) Jakie i pod jaką nazwą przynosi do aptek na sprzedaż? 66) Jakie zioła są środkami zabobonnymi ${ }^{18}$ lub czarodziejskimi ludu np. lubczyk, nasięźrzał

\footnotetext{
10. W oryginale: "pomódz".

11. J. Rostafiński, Odezwa, dz. cyt.

12. W oryginale: "przytem".

13. W oryginale: „właściwem".

14. W oryginale: "ludowem".

15. J. Rostafiński, Odezwa, dz. cyt.

16. W oryginale: "wilję".

17. J. Rostafiński, Odezwa, dz. cyt.

18. W oryginale: „zabobonnemi”.
} 
lub inne, jak je lud używa?"19 Zdaje się, że to ostatnie pytanie, a właściwie odpowiedź na nie, stało się dla Rostafińskiego inspiracją do powstania Zielnika, który jest niezwykle ciekawym opracowaniem dotyczącym wykorzystania ziół w życiu religijnym i przypisywania im niezwykłych mocy. To, w jaki sposób Rostafiński interpretował te wyniki, postaramy się przybliżyć nieco dalej.

Autor Odezwy uprasza też respondentów "o rozszerzenie tej Odezwy pomiędzy wszystkimi ${ }^{20}$ osobami mającymi ${ }^{21}$ styczność z ludem jak ziemianie, kapłani, nauczyciele, lekarze, aptekarze [...]"22. Dobór grupy docelowej, do której skierowana była Odezwa, był nieprzypadkowy. Po pierwsze, byli to zazwyczaj jedyni mieszkańcy wsi mający umiejętność czytania i pisania, po drugie zaś stanowili pewien autorytet lokalny, przez co mieli pewną siłę sprawczą, dzięki której mogli nakłaniać mieszkańców do podzielenia się swoją wiedzą. Co ciekawe, wiedza ta i praktyki z nią związane często były sprzeczne z religią i medycyną. Zwłaszcza ta ostatnia dziedzina w okresie pozytywizmu kierowała się ku - rozpoczynającym swe panowanie - środkom chemicznym. Medycyna naukowa coraz bardziej wypierała nawet z terenów wiejskich medycynę ludową preferującą ziołolecznictwo i związane z nią obrzędy magiczne i przesądy.

\section{Listy do Rostafińskiego}

Dla lepszego zobrazowania zbioru odpowiedzi na odezwę Rostafińskiego warto przytoczyć kilka listów, które w minimalnym stopniu zobrazują pracę wykonywaną przez krakowskiego uczonego. Pierwsza z trzech wybranych osób to najprawdopodobniej Józefa z Łempickich Morawska ${ }^{23}$. Na jej autorstwo wskazują miejscowość, z której kieruje swój list, tj. Jurkowo ${ }^{24}$ znajdujące się wówczas w rejencji poznańskiej, oraz odniesienia w tekście do osoby "Kazia", czyli - jak możemy wnioskować - Kazimierza Morawskiego ${ }^{25}$, późniejszego rektora Uniwersytetu Jagiellońskiego. Treść jej

19. J. Rostafiński, Odezwa, dz. cyt.

20. W oryginale: „wszystkiemi".

21. W oryginale: „mającemi”.

22. J. Rostafiński, Odezwa, dz. cyt.

23. Józefa Dzierżykraj-Morawska z Łempickich (1822-1895), polska ziemianka z Wielkopolski. Morawscy posiadali majątek w Jurkowie.

24. Jurkowo - wieś w województwie wielkopolskim, powiecie kościańskim, gminie Krzywiń.

25. Kazimierz Morawski (1852-1925), polski profesor, filolog klasyczny, rektor UJ i prezes PAU. Zob. K. Grodziska-Ożóg, Cmentarz Rakowicki w Krakowie (18o3-1939), Kraków 1987, s. 127. 
listu jest bardzo ciekawa, a to ze względu na stosunek zamożnej ziemianki do spraw kultury ludowej i przybliżenie w nim relacji społecznych. Ten list jest bezpośrednią odpowiedzią na Odezwę Rostafińskiego. Dwóch pozostałych korespondentów było łatwiej zidentyfikować, gdyż są to osoby zasłużone dla historii kultury i nauki polskiej: Paweł Smolikowski CR ${ }^{26}$ i Jan Karłowicz ${ }^{27}$.

\section{List Józefy z Łempickich Morawskiej}

Pierwszy z wybranych do przybliżenia listów został wysłany przez wspomnianą już Józefę z Łempickich Morawską. Korespondencja dotyczy wprost odpowiedzi na Odezwę, dlatego też prezentujemy ją jako pierwszą. List jest datowany na 23 sierpnia 1883 r. Autorka pisze: "Najprzód tysiącznie dziękuję za przysłanie mi odbitki felietonu, w którym opis Krakowa już przed kilkoma tygodniami nas zachwycił, rada bym się za pamięci odwdzięczyć ale niestety! Nie wielką mam nadzieję dostarczenia Panu żądanych wiadomości. U nas stare wyrażenia zachowały się u włościan, wyższe zaś klasy zbyt mało maja interesu do podobnych kwestii ${ }^{28}$. Najlepiej może duchowieństwo potrafiłoby udzielić odpowiedzi na większą część zapytań Pańskich.

Co do znaczeń wzięłam już na egzamin najmądrzejszego chłopa wsi naszej, i tyle tylko się dowiedziałam ze kartofle po polsku ${ }^{29}$ nazywają się pyrki! ${ }^{30}$

26. Paweł Smolikowski CR (1849-1926), polski ksiądz katolicki, zmartwychwstaniec. Doktor teologii, pisarz. Generał zakonu Zgromadzenia Zmartwychwstańców. Rektor Papieskiego Kolegium Polskiego w Rzymie, archimandryta bułgarski, Sługa Boży Kościoła katolickiego. Zob. J. Mrówczyński CR, http://www.biz.xcr.pl/files/Mrowczyski-Smolikowski-CR. pdf (07.03.2017).

27. Jan Aleksander Ludwik Karłowicz (1836-1903), polski etnograf, językoznawca. Zob. Jan Aleksander Karłowicz, "Laboratorium Kultury" 4 (2015). Cały rocznik czasopisma poświęcony jest dorobkowi tego uczonego

28. W oryginale: "kwestyj".

29. Słowo podkreślone ręką autora listu.

30. J.w. 
Spróbuję szczęścia z innymi, ale nasza okolica najmniej zapewne dostarczy wiadomości, w innych częściach Księstwa ${ }^{31}$ prędzej się dochowały starodawne nazwy i obyczaj. Zapewne to Kazio rozsławił aż w Krakowie sławę Józefki, i skazał mnie na konfrontację z tą czarownicą. Choć przysłużeniu się łaskawemu Panu zniewoli mnie do szukania informacji nawet $\mathrm{w}$ tym ${ }^{32}$ mętnym ${ }^{33}$ źródle, tym ${ }^{34}$ mętniejszym ${ }^{35}$, że baba prawie zawsze pijana, najlepsze robi interesy ${ }^{36}$ na handlowaniu tajemniczą rośliną którą zwie odczyńcem $^{37}$, skoro nią się odczynia ${ }^{38}$ uroki. Próbki chętnie nadeślę jeśli dojdę do porozumienia z tą wiedźmą. Tymczasem dwa tylko wyrazy załączam: raz, że w Śląsku ${ }^{39}$ (co zapewne już panu wiadomo) żyto dotąd nazywają reż ${ }^{40}$, a pszenicę bardzo często żytem. Po wtóre ${ }^{41}$ ze na naszych Kujawach, wielkopolska purka ${ }^{42}$ ogólnie nazywana jest pantówką". W dalszej części listu Morawska wylicza 38 osób, z którymi Rostafiński mógłby podjąć kontakt, by uzyskać dodatkowe informacje. Wyjaśniając Rostafińskiemu, na kogo powinien najbardziej zwrócić uwagę, deklaruje też swoją pomoc w słowach: „Nie przestanę się za tym ${ }^{43}$ krzątać, wiedząc ile uwagi Szanowny Pan przywiązuje do każdego szczegółu"44.

Z przedstawionej odpowiedzi wynika, że autorytet Rostafińskiego inspirował do poświęcenia się osoby z „klas wyższych", które dotychczas

\footnotetext{
31. Chodzi o Księstwo Poznańskie, zabór pruski.

32. W oryginale: "tem".

33. W oryginale: "mętnem".

34. W oryginale: „tem"

35. W oryginale: „mętniejszem".

36. W oryginale: „interesa”.

37. Słowo podkreślone ręką autora listu.

38. Słowo podkreślone ręką autora listu.

39. W oryginale: "Szląsku".

40. Słowo podkreślone ręką autora listu.

41. W oryginale: „Powtóre".

42. Ziemniak.

43. W oryginale: "za tem".

44. APA, List Józefy Morawskiej do Józefa Rostafińskiego, rkps, Jurków, 23 VIII 1883. List składający się z sześciu stron, pisany piórem niebieskim atramentem na papierze czerpanym z pionowymi pasami znaków wodnych. Naklejka z numerem "206" zakrywająca początek zwrotu grzecznościowego "Szano", czerwoną kredką dopisana litera "K". Stronica piąta listu ma naklejkę bez numeru, zakrywającą jedno słowo, które zostało przepisane innym stylem, zielonym ołówkiem „w Ostrowie". Na stronicy piątej dopisana czerwoną kredką litera "K" oraz ołówkiem "ad 279" wskazujące na odniesienie do innego numeru listu.
} 
zjawisko tradycji i kultury ludowej traktowały jako coś właściwego dla analfabetycznego ludu, nie zaś za obiekt godny badania naukowego.

\section{Listy Pawła Smolikowskiego CR}

Jedną z ciekawszych osób, z którymi korespondował Józef Rostafiński, jest wspomniany Paweł Smolikowski CR. Ten uczony zmartwychwstaniec, badający kulturę Bułgarii, odpowiadał Rostafińskiemu na listy, w których krakowski profesor prosił go o wyjaśnienia dotyczące konkretnych spraw związanych z językiem i życiem wsi bułgarskiej. List pierwszy jest datowany na 23 sierpnia 1883 r. Smolikowski w sposób bardzo zażyły zwraca się do Rostafińskiego. Na początku korespondencji pisze: „Kochany i Łaskawy Kolego, Osobiście nie mogę Ci służyć w tej chwili w rzeczy o której piszesz, bo bardzo wiele mam teraz do roboty, jak zwykle przed zaczęciem szkoły i w początkach - zresztą bardzo mało zajmowałem się rzeczami botanicznymi, tak że nawet po polsku bardzo mało nazw technicznych rozumiem. Polaka który by mógł w tym względzie pomóc, w Bułgarii ${ }^{45}$ nie znam. Jest słownik francusko-bułgarski i bułgarsko-francuski. Można go dostać w Filiopoli w księgarni Danowa ${ }^{46}$. Słownik ten wydał Bogorów Kantoja ${ }^{47}$ za 20 franków. Mam tu przy sobie Bułgara, naszego ucznia z Adryamopola, przysłanego do nas by nauczał na Uniwersytecie we Lwowie. Umie on trochę po polsku - więc mu dałem Twoją odezwę - kazałem mu zrobić notatkę po bułgarsku - jeśli co z tego będzie to przetłumaczymy na polski - będę rad posłać Ci i tym sposobem choć pośrednio Ci służyć"48.

W drugim liście Smolikowski tłumaczy znaczenie kilku słów związanych z rolnictwem, które udało mu się - dzięki studentowi z Bułgarii Chrysto Kosiakofi ${ }^{49}$ - wytłumaczyć. Przeprasza też Rostafińskiego, że nie może zbyt dużo mu wyjaśnić w związku z badaną kwestią. Usprawiedliwia się następująco: „Jak kochany Kolega mógł zauważyć, podał mi nasz Bułgar tylko te nazwy, które podobne mają brzmienie co polskie, innych nie rozumie po polsku, a że ja w botanice bardzo słaby i wsi prawie nigdy nie widziałem, nie mogłem mu więcej wytłumaczyć. [...] Żal mi, że tak małym ${ }^{50}$

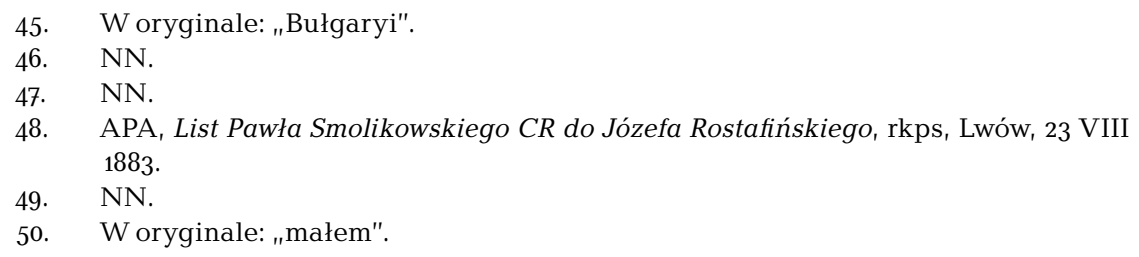




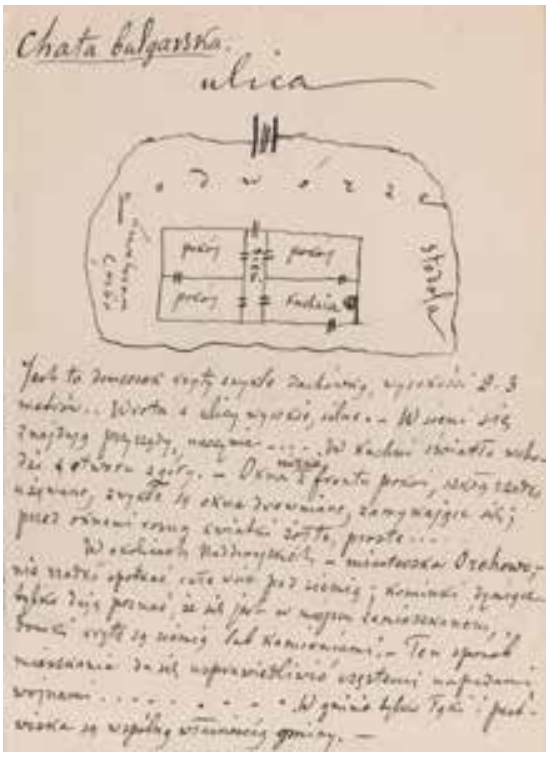

4. Notatka z listu P. Smolikowskiego CR do J. Rostafińskiego, APA mogę Ci służyć ale przyjmij ${ }^{51}$ i to jako dowód mojej do Ciebie przyjaźni i uszanowania"52. Trudno powiedzieć, do czego te dane były potrzebne Rostafińskiemu. Zapewne listów tych w następnych latach było sporo, jednak w zbiorze zachował się jeszcze jeden, datowany na 9 marca 1887 r. Jest on najkrótszy w treści głównej, jednak też najbardziej intrygujący, gdyż Smolikowski przesyła w nim rysunek chaty bułgarskiej. Pisze, "[...] posyłam Ci notatkę jednego z naszych Bułgarów i polecając się Twojej pamięci i przyjaźni zostaję kochającym Cię kolegą i sługą w Panu"53.

Trudno jednoznacznie określić, czy korespondencja ze Smolikowskim została użyta przy opracowaniu Zielnika. Być może dotyczyła jego pracy Polska z czasów przedhistorycznych ${ }^{54}$, do której przysyłał mu materiały i udzielał konsultacji kolejny z wybranych autorów listów, Jan Karłowicz.

\section{Listy od Jana Karłowicza}

W zbiorze Wilczyńskiego, znajdujemy też trzy listy od Jan Karłowicza. Dotyczą one - jak wspominaliśmy przygotowywanej przez Rostafińskiego pracy Polska z czasów przedhistorycznych. List pierwszy jest dość specyficzny, gdyż Karłowicz pisze go na czwartej stronie listu ks. Hórnika ${ }^{55}$ i dołącza do niego osobną kartkę,

51. W oryginale: "przyjm".

52. APA, List Pawła Smolikowskiego CR do Józefa Rostafińskiego, rkps, Lwów, 7 IX 1883.

53. APA, List Pawła Smolikowskiego CR do Józefa Rostafińskiego, rkps, Lwów, 8 III 1887.

54. J. Rostafiński, Polska z czasów przedhistorycznych pod względem fizyograficznym i gospodarskim, rzecz czytana na publicznem posiedzeniu Akademii umiejętności $w$ d. 21 maja 1887 r., w: "Rocznik Zarządu Akademii Umiejętności" 8 (1887), s. $113-153$.

55. W oryginale: „Hornik”. Chodzi o Michała Hórnika (1833-1894), łużyckiego księdza katolickiego, profesora slawistyki, publicystę. Zob. B. Tomiak, Michał Hórnik - duchowy orędownik polskości na Łużycach, "Nasze Historie" 1999 nr 4 , s. $19-22$ 
na której przesyła Rostafińskiemu „wypis dotyczący miejsca z rozprawy Brücknera"56. Wypis dotyczył pracy Die Slavischen Ansiedelung in der Altmark und in Magdeburgischen ${ }^{57}$. W liście informuje też Rostafińskiego, że nie posiada tej pracy, zatem nie może mu pomóc. W korespondencji Karłowicz wyjaśniał również krakowskiemu badaczowi językowe znaczenie pojęć stosowanych przez niego lub też tych, które chciał on zastosować. W liście z 29 maja 1887 r. - pisanym z Drezna - Karłowicz tłumaczy m.in.: słowo „Podruna". Jego etymologię wyjaśnia następująco: "Podruna ${ }^{58}$ albo Podrum ${ }^{59}$ z greck. hippodromos; w starosłowiańskim ma toż znaczenie, ale w innych słowiańskich znaczy piwnica, sklep; zapewne było jakieś znamię wspólne $\mathrm{cyrku}^{60}$ i piwnicy ${ }^{61}$, które umożliwiło przejście znaczenia; po bułgarsku i serbsku podrum ${ }^{62}$; nowo grec. $\pi$ ov $\delta \rho o v ́ \rho \mu$; rumuńsk. i tureck. podrom. Do nas wyraz dostał się zapewne przez rumuńskie pośrednictwo"63. W tym samym liście Karłowicz zapytuje Rostafińskiego, komu ma podziękować za przedstawienie go na członka Akademii Umiejętności w Krakowie.

Druga część wiadomości zawiera ciekawy ustęp dotyczący pokrewieństwa słów „ulica” i „ul”, o które zapytywał Karłowicza Rostafiński. Karłowicz odpowiada następująco: "Co do ulica ${ }^{64}$ i ul ${ }^{65}$, sprawa podejścia znaczenia ciemna, choć pokrewieństwo jasne. Nie należy zapominać, że w zabytkach naszych i dziś u Kaszubów uliczka ${ }^{66}$ znaczy drzwi ${ }^{67}$. Mnie się zdaje, że pierwsze chaty okrągłe zwano ulami ${ }^{68}$, a na ul pszczelny z nich z czasem przeniesiono [...]"69. Poza wyjaśnieniem pokrewieństwa etymologicznego między tymi dwoma pojęciami ciekawe wydaje się stwierdzenie Karłowicza, w którym mówi o języku jako "zabytkach naszych" - jest to bardzo interesujące określenie, wskazujące na znaczenie, które Karłowicz

56. APA, List Jana Karłowicza do Józefa Rostafińskiego, rkps, Drezno, 12 III 1887.

57. A. Brückner, Die Slavischen Ansiedelung in der Altmark und in Magdeburgischen, Leipzig 1887.

58. Słowo podkreślone ręką autora listu.

59. Słowo podkreślone ręką autora listu.

60. Słowo podkreślone ręką autora listu.

61. Słowo podkreślone ręką autora listu.

62. Słowo podkreślone ręką autora listu.

63. APA, List Jana Karłowicza do Józefa Rostafińskiego, rkps, Drezno, 28 V 1887.

64. Słowo podkreślone ręką autora listu.

65. Słowo podkreślone ręką autora listu.

66. Słowo podkreślone ręką autora listu.

67. Słowo podkreślone ręką autora listu.

68. Słowo podkreślone ręką autora listu.

69. APA, List Jana Karłowicza do Józefa Rostafińskiego, rkps, Drezno, 28 V 1887. 
dawał tradycyjnemu językowi. Język jest bowiem dziedzicem kultury i w nim, a właściwie w jego rozwoju przejawia się jej ciągłość i jakość. Grupy etniczne niemające rozbudowanego języka nie wykształcają też bogatej kultury.

Drugi list jest datowany na 2 czerwca 1887 r. i ma charakter osobisty. Karłowicz wyjaśnia Rostafińskiemu, dlaczego bardzo długi czas zajmuje mu praca nad dalszą częścią Słownika etymologicznego ${ }^{70}$. Argumentuje to tym, że od czasu gdy się jej podjął, powstało sporo nowych publikacji, które musiał przeczytać i włączyć do części "słownika już do druku przygotowanych; a wcielić to, znaczyło przepisać na nowo! Niektóre z pierwszych liter trzy razy przerabiałem i przepisywałem!"71. Tłumaczenie to miało powód. Było nim zarzucanie Karłowiczowi nieterminowości wydania dalszych części Słownika. Najbardziej bolesne dla niego były zarzuty córki Linde$\mathrm{go}^{72}$, którego nagrodę za odręcznie napisane początki Słownika otrzymał w 1879 r.

Pisze o tym do Rostafińskiego następująco: „Pani Górecka ${ }^{73}$, Lindówna z domu, znana w całej Warszawie jędza, ogadywała mię gdzie mogła, nudziła Akademię dopominkami swoimi ${ }^{74}$, groziła cofnięciem zapisu itd. ${ }^{75}$ Pan Estreicher ${ }^{76}$ dwa lata temu obdarzył mię wysoce przykrym listem, w którym nie pytając o powody opóźnienia, zarzuca mi nierzetelność itd. ${ }^{77}$ Mówiąc między nami, dawno bym Akademii zwrócił z procentami ową premię ${ }^{78}$, bo nie dla niej pracowałem i dzięki losowi mogłem i mogę bez zasiłków znikąd ${ }^{79}$ bądź pracować; ale nie chciałem rozgłosu, skandalu, gawęd i niedorzecznych komentarzy"80. Karłowicz wyjaśnia również, że jeśli ktoś

70. J. Karłowicz, Słownik wyrazów obcego a mniej jasnego pochodzenia, Kraków 1905.

71. APA, List Jana Karłowicza do Józefa Rostafińskiego, rkps, Drezno, 2 VI 1887.

72. Samuel Bogumił Linde (1771-1847), polski profesor, językoznawca, leksykograf, bibliograf. Zob. J. Michalski, Linde Samuel Bogumił (1771-1847), w: Polski Słownik Biograficzny, t. 17, Wrocław 1972, s. 360-361.

73. Ludwika Dominika Eleonora Górecka (1815-1900), córka Samuela Lindego, fundatorka stypendium im. S. B. Lindego.

74. W oryginale: "swojemi".

75. W oryginale: „i t.d.".

76. Karol Teofil Józef Estreicher (1827-1908), polski profesor, historyk literatury. Zob. A. Birkenmajer, Estreicher Karol Teofil Józef (1827-19o8), w: Polski Słownik Biograficzny, t. 6, Kraków 1948, s. 309-312.

77. W oryginale: „i t.d.".

78. W oryginale: „premję".

79. W oryginale: "znikądkolwiek".

80. APA, List Jana Karłowicza do Józefa Rostafińskiego, rkps, Drezno, 2 VI 1887. 
uważnie czytał jego wstęp do części pracy przygotowanej w rękopisie, to zrozumie, że nie mogła się ona tak szybko posunąć, gdyż zaszły niezależne od jego woli "przeszkody".

W dalszej części listu Karłowicz wyjaśnia też Rostafińskiemu, że nie pisze do niego o tym dlatego, by starać się o członkostwo w akademii, ale aby wytłumaczyć powody długiej pracy, która miała przyczyny merytoryczne, a nie wynikające z jego niechęci. To drugie rozjaśnienie problemu jest związane z pierwszym listem Karłowicza, a dotyczy jego członkostwa w Akademii Umiejętności. Karłowicz - kontynuując ten wątek - pisze do Rostafińskiego następująco: „Przepraszam, jeślim znudził Pana obszernym wywodem. Nie pisałem go dlatego, ażeby się dobijać członkostwa Akademii. Uważam je za wysoki zaszczyt, ale się o nie nie starałem, i starał się nie będę, nasamprzód dlatego, że mam szczere przekonanie, iż wielu jest ludzi daleko zasłużonych ode mnie, którzy go jeszcze nie dostąpili (że wspomnę np. Korzona ${ }^{81}{ }^{1}$ Baudouina ${ }^{82}$, Brücknera ${ }^{83}$, przyrodników warszawskich, Smoleńskiego ${ }^{84}$ etc. etc.), a po wtóre, że nie leży to w mojej naturze, ażebym szukał tego, co, jeżeli zasłużę istotnie, samo przyjdzie. Rozpisałem się jedynie z tej przyczyny, żeś mię, Szanowny Panie o to spytał, a mając Go za człowieka prawego, pragnąłem stanąć przed nim oczyszczony"85. Treść listów Karłowicza pokazuje determinację i klasę tego badacza, a także trud, który wkładał, by rzetelnie dotrzeć do obranego przez siebie celu. Co zresztą i osiągnął, pracując nad nim do końca swojego życia, czyli do 1903 r.

Całość zbioru odpowiedzi z kolekcji Wilczyńskiego domykają spisy treści przygotowane przez Rostafińskiego w 1888 r. Każdy z nich ma różne tytuły. Warto w tym miejscu przywołać obydwa, gdyż pokaże to, jak

81. Tadeusz Korzon (1839-1918), polski profesor, historyk. Zob. W. Konopvczyński, Korzon Tadeusz Sylwester (1839-1918), w: Polski Słownik Biograficzny, t. 14, Wrocław-Warszawa-Kraków 1968-1969, s. 178-181.

82. Jan Niecisław Ignacy Baudouin de Courtenay (1845-1929), polski profesor, językoznawca. Zob. S. Lam red., Trzaski, Everta i Michalskiego Leksykon Ilustrowany, Kraków 1931, s. 165.

83. Aleksander Brückner (1856-1939), polski profesor, slawista, historyk, językoznawca. Zob. W. Berbelicki, Aleksander Brückner (1856-1939), Warszawa 1989.

84. Najprawdopodobniej chodziło o Kazimierza Smoleńskiego (1876-1943), polskiego profesora, chemika. Zob. S. Zamecki, Kazimierz Smoleński, „Przemysł Chemiczny" 75 (1996) nr 5, s. 189-190.

85. APA, List Jana Karłowicza do Józefa Rostafińskiego, rkps, Drezno, 2 VI 1887. 
dojrzewała praca Rostafińskiego. Tytuł pierwszy: Rośliny ${ }^{86}$ ludu Polskiego i Ruskiego pod względem: gospodarskim, lekarskim, guślarskim oraz zwyczajowym. Rzecz na podstawie materiałów nadesłanych ze wszystkich stron Kraju, zestawił $i$ z uwzględnieniem literatury opracował Józef Rostafiński ${ }^{87}$. Tytuł drugi: Rośliny naszego ludu pod względem gospodarskim, lekarskim, guślarskim oraz zwyczajowym. Na podstawie materiałów nadesłanych z ze wszystkich stron kraju zestawit ${ }^{88}$ Józef Rostafiński ${ }^{89}$. Ostatecznie żaden z tych tytułów nie został wykorzystany.

\section{Kilka uwag o Zielniku czarodziejskim}

Jak wspominaliśmy we wstępie, dziełem, które powstało na bazie wyników Odezwy, był Zielnik Czarodziejski, to jest zbiór przesadów o roślinach. Praca powstała nie tylko w oparciu o wyniki badań empirycznych. Rostafiński badał wiele lat księgi medyczne i pozycje, które opisywały zwyczaje i praktyki ludowe. Co więcej, jako empiryk chciał też zweryfikować tezę o pogańskim pochodzeniu praktyk związanych z używaniem ziół przez lud. Już na pierwszej stronie swojej pracy, o tym, że nie przyjmuje tej tezy a priori, pisze następująco: „Prawie wszyscy autorzy ${ }^{90}$, piszący u nas o tym przedmiocie, piszą z przekonaniem z góry powziętym ${ }^{91}$, że to, co z wierzeń o roślinach żyje wśród ludu, jest prastarym pogańskim wyobrażeniem. Nie silą się $\mathrm{Ci}$ autorzy ${ }^{92}$ na żadne pod tym względem dowodzenia"93. Dalej dowodzi, że był początkowo skłonny przyjąć tę tezę, jednak dogłębnie badając materiał empiryczny, który zgromadził, uznał, że jest to przesąd naukowy, który raczej mitologizuje, a nie podaje prawdę opartą na badaniach empirycznych i teoretycznych.

86. Pomiędzy słowem „rośliny" a „ludu" Rostafiński pierwotnie wpisał słowo „naszego", które jednak wykreślił. Część tytułu „Rośliny ludu polskiego" podkreślona podwójną linią ciągłą. Również słowa „gospodarskim, lekarskim, guślarskim oraz zwyczajowym" podkreślone pojedynczą równą linią ciągłą z małym dodatkiem linii podwójnej.

87. APA, J. Rostafiński, Spis treści, rkps, 13 I 1888.

88. Po słowie „zestawił" Rostafiński wykreślił słowa „i z uwzględnieniem literatury opracował". Podpis Rostafińskiego podkreślony falującą linią.

89. $\quad$ APA, J. Rostafiński, Spis treści, rkps, 13 I 1888.

90. W oryginale: „autorowie".

91. W oryginale: "powziętem".

92. W oryginale: „autorowie".

93. J. Rostafiński, Zielnik Czarodziejski, to jest zbiór przesądów o roślinach, Katowice 2016, s. 1. 
Poddając krytyce publikacje odnoszące się do tezy o pogańskim pochodzeniu wierzeń o roślinach, Rostafiński pisze: „Im dokładniej rzecz badałem, tym ${ }^{94}$ bardziej kurczył się zasób tych roślin, które można było uważać jako znane i używane przez nasz lud, przed wprowadzeniem chrześcijaństwa do Polski. Doszedłem wreszcie do przekonania, że chrześcijaństwo i idąca w ślad za nim kultura zatarły zupełnie pierwotne wyobrażenia pogańskiego ludu. Należało wobec tego dowieść, jakim sposobem wpływy tej kultury sięgały do ludu. Gdybym pisząc o tym przedmiocie powiedział gołosłownie, że w pewnym okresie ta kultura sięgała do ludu za pośrednictwem popularnej literatury polskiej, nie bardzo dano by mi wiarę. Zanim więc ogłoszę osobną co do tego rozprawę, podaję tu materiał na poparcie tej jednej tezy, jaką tam gruntownie uzasadnię"95. A, jak dowiadujemy się nieco dalej z jego wypowiedzi, badał literaturę związaną z tą tematyką bardzo dokładnie. O swoich dociekaniach pisze następująco: „wszystkie te dzieła przejrzałem od deski do deski szukając w nich przesądów o roślinach. Jeśli się zważy, ile ich jest i że sam Syreńskiego ${ }^{96}$ Zielnik $^{97}$ ma przeszło 1500 stron in folio, można nabrać wyobrażenia, ile to wymagało pracy"98. Ogrom pracy Rostafińskiego był z pewnością znaczący, tak jak znaczący jest jego wynik.

Warto przybliżyć kilka ciekawszych przykładów znaczenia roślin w kulturze ludowej. Rostafiński pisze: „Dymu z dębu czart się boi"99; dziurawiec jest „wielkim ratunkiem przeciw naigrawaniu ${ }^{100}$ szatańskiemu,

94. W oryginale: "tem".

95. J. Rostafiński, Zielnik Czarodziejski..., dz. cyt., s. 2.

96. Szymon Syreński „Syreniusz" (ok. 1540-1611), polski profesor, lekarz i botanik. Zob. G. Brzęk, Syreński (Syreniusz) Szymon (1541-1611), w: Słownik biologów polskich, red. S. Feliksiak, Warszawa 1987, s. 517.

97. Sz. Syreński, Zielnik Herbarzem z ięzyka Łacinskiego zowią. To iest Opisanie własne imion, kształtu, przyrodzenia, skutkow, y mocy Zioł wszelakich Drzew, Krzewin y korzenia ich, Kwiátu, Owocow, Sokow Miasg, Zywic y korzenia do potraw zaprawowania. Tak Trunkow, Syropow, Wodek, Likworzow, Konfitor, Win rozmaitych, Prochow, Soli z zioł czynioney; Maści, Plastrow. Przytym o Ziomach y Glinkach rożnych: o Kruscach Perłach y drogich Kamieniach. Tez o zwierzetach czworonogich, czołgajacych Ptastwie, Rybach y tych wszystkich rzeczach ktore od nich pochodza od DIOSCORIDA z przydaniem y dostatecznym dokładem z wielu innich o tey materiey piszacych, z położeniem własnych figur dla snadnieyszego ich poznania a y używania ku zatrzymaniu zdrowia tak ludzkiego iako bydlecego y chorob przypadłych odpedzenia, z wielkiem uważaniem y rozsądkiem Polskiem iezykiem zebrany y na osmiero ksiag rozłożony, Kraków 1613.

98. J. Rostafiński, Zielnik Czarodziejski..., dz. cyt., s. 3.

99. J. Rostafiński, Zielnik Czarodziejski..., dz. cyt., s. 177.

100. W oryginale: „nagrawaniu". 
odgania i strzeże od nich, nosząc go na sobie zawsze"101; wrotycz: "gdyby którą białą głowę sczarowano, iżby z gorącej miłości wszczął się jej niepokój, a iżby rozumiała, żeby była dziewka, a i żeby ${ }^{102}$ panieństwo miała stracić, tedy się niech w tej wrotyczy myje, odejdą od niej te czary"103; lebiodka ${ }^{104}$ biała: „kto chce dojść pod którą planetą się urodził, jeżeli jest niepokalany ma lebiodkę ${ }^{105}$ wyrwać przez chustkę i czekać, aż w chlebie znajdzie pszeniczne ${ }^{106}$ ziarno, wówczas złączywszy je, ma obie rzeczy włożyć pod poduszkę i modlić się do siedmiu planet, żeby mu tę kwestię ${ }^{107}$ objawiły przez sen"108.

W swojej publikacji Rostafiński pozostawił nam niezwykły obraz wsi, która już zupełnie zaginęła. Wsi, która była związana niemożliwymi już nawet do wyobrażenia relacjami kulturowymi, w której magia przeplatała się z religią, wiara z zabobonem. Samo zaś życie było związane ze stałym cyklem przyrody. Człowiek odnosił się do świata przyrody z szacunkiem, widząc w nim źródło swego życia, ale też i z lękiem. Misterium fascinosum i misterium tremendum wobec natury miały uzasadnioną od wieków postawę. Człowiek realnie czuł się częścią tego, co powstaje i ginie w sposób przygodny. Zdawał sobie sprawę, że brak wiedzy o prawach natury może być dla niego zgubny, a wiedza przekazywana z pokolenia na pokolenie, zwłaszcza ta dotycząca środków leczniczych, była cenna i mogła dać mu możliwość dłuższego i bezpieczniejszego życia.

\section{Zakończenie}

Dzieło Rostafińskiego - jak na czasy, w których się go podją - było niezwykle istotne i wniosło bardzo znaczny wkład do badań nad historią kultury i etnobotaniki ${ }^{109}$. Znaczenie zachowanego przez Wilczyńskiego zbioru dokumentów po Rostafińskim jest z pewnością bardzo ważne i przyniesie - po dokonaniu pełnej edycji - wiele niespodzianek tak dla

\footnotetext{
101. J. Rostafiński, Zielnik Czarodziejski..., dz. cyt., s. 177.

102. W oryginale: „iżeby".

103. J. Rostafiński, Zielnik Czarodziejski..., dz. cyt., s. 180.

104. W oryginale: "lebiotka".

105. W oryginale: "lebiotkę".

106. W oryginale: „przeniczne”.

107. W oryginale: „kwesyę".

108. J. Rostafiński, Zielnik Czarodziejski..., dz. cyt., s. 181.

109. O etnobotanice i jej znaczeniu w Polsce pisze Piotr Klepacki. Zob. P. Klepacki, Etnobotanika w Polsce $i$ jej znaczenie, "Analecta - Studia i Materiały z Dziejów Nauki" 16 (2007) nr 1-2, s. 191-245.
} 
historyków nauki - w szczególności botaniki - jak i dla antropologów kulturowych zajmujących się kulturą wsi polskiej. Dzieło Rostafińskiego ma znaczenie nie tylko jako historyczny materiał źródłowy, ale służy również do odtwarzania przepisów leczniczych, które zostały zarzucone w czasie postępującej chemizacji.

Czy praca Rostafińskiego w pełni odpowiada na to, że większość wyobrażeń i przesądów ludowych wywodzi się z kultury chrześcijańskiej - trudno powiedzieć. Być może Rostafiński nie był świadom tego, że chrześcijaństwo adaptowało dosyć sporo obrzędów pogańskich. Niewątpliwą zasługą Rostafińskiego było przeprowadzenie Odezwy, jak również zawarcie w niej pytań o charakterze bardzo ogólnym. Rostafiński wykazał się przy tym - być może nieuświadomioną nawet roztropnością, która do dziś daje obraz i możliwość badań antropologicznych, botanicznych i historycznych.

Postać Józefa Rostafińskiego jest wybitnym przykładem tego, w jaki sposób uczony przyrodnik może pogodzić swoją wiedzę z pasją, która w ostatecznym wymiarze daje ponownie treści do dalszych badań - i to kilku pokoleniom uczonych - po jego śmierci. W tym też kontekście odnaleziony zbiór, w którym większość dokumentów stanowią odpowiedzi na Odezwę Józefa Rostafińskiego, będzie poddany edycji, przez co ma stać się materiałem do dyskusji naukowej dla badaczy z dziedziny nauk przyrodniczych i humanistycznych. Materiał zebrany przez Rostafińskiego jest niezwykle cenny i zapewne stanie się przyczynkiem do dalszych publikacji naukowych.

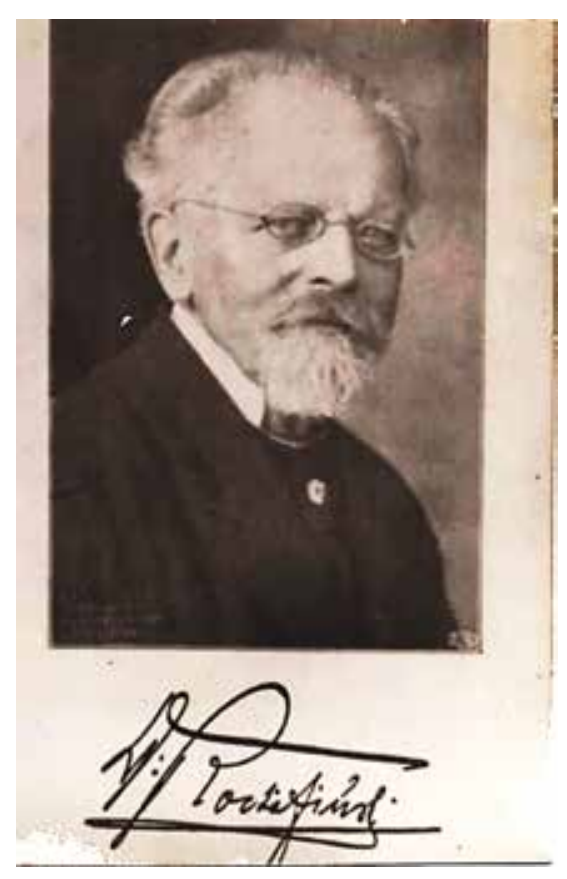

5. Prof. J. Rostafiński (1850-1925), APA 


\section{Bibliografia}

W. Berbelicki, Aleksander Brückner (1856-1939), Warszawa 1989.

A. Birkenmajer, Estreicher Karol Teofil Józef (1827-19o8), w: Polski Słownik Biograficzny, t. 6, Kraków 1948.

A. Brückner, Die Slavischen Ansiedelung in der Altmark und in Magdeburgischen, Lipsk 1897.

G. Brzęk, Syreński (Syreniusz) Szymon (1541-1611), w: Słownik biologów polskich, red. S. Feliksiak, Warszawa 1987, s. 517.

H. Bukowiecki, Raciborski Marian (1863-1917), w: Słownik biologów polskich, red. S. Feliksiak, Warszawa 1987, s. 441-443.

H. Bukowiecki, Rostafiński Józef Tomasz (1850-1928), w: Słownik biologów polskich, red. S. Feliksiak, Warszawa 1987, s. 453-454.

K. Duda, Tadeusz Wilczynski (1888-1981) and Josef Treshka (19o6-1945): images of the forgotten world, „Вісник Кам' янець-Подільського національного університету імені Івана Огієнка: Історичні науки" 2016 nr 9, s. 406-417.

A. Gordijewska, Prezentacja Katalogu polskich medalionów i medali we Lwowie, "Kurier Galicyjski” 2016 nr 4 (268), s. 12.

K. Grodziska-Ożóg, Cmentarz Rakowicki w Krakowie (1803-1939), Kraków 1987.

J. Karłowicz, Słownik wyrazów obcego a mniej jasnego pochodzenia, Kraków 1905.

P. Klepacki, Etnobotanika w Polsce i jej znaczenie, "Analecta - Studia i Materiały z Dziejów Nauki" 16 (2007) nr 1-2, s. 191-245.

W. Konopczyński, Korzon Tadeusz Sylwester (1839-1918), w: Polski Słownik Biograficzny, t. 14, Wrocław-Warszawa-Kraków 1968-1969, s. $178-181$.

P. Köhler, Ankieta Józefa Rostafińskiego z 1883 roku dotyczaca ludowego i użytkowania roślin w Polsce, "Analecta - Studia i Materiały z Dziejów Nauki" 2 (1993) nr 2, 4, s. 87-119.

P. Köhler, Rośliny święcone $w$ ankiecie Józefa Rostafińskiego (1850-1928) z 1883 r., "Etnobiologia Polska" 6 (2016), s. 129-190.

"Laboratorium Kultury" 4 (2015), s. 129-190. 
List Jana Karłowicza do Józefa Rostafińskiego, rkps, Drezno, 12 III 1887.

List Józefy Morawskiej do Józefa Rostafińskiego, rkps, Jurków, 23 VIII 1883.

List Pawła Smolikowskiego CR do Józefa Rostafińskiego, rkps, Lwów, 23 VIII 1883.

List Pawła Smolikowskiego CR do Józefa Rostafińskiego, rkps, Lwów, 7 IX 1883.

List Pawła Smolikowskiego CR do Józefa Rostafińskiego, rkps, Lwów, 8 III 1887.

J. Michalski, Linde Samuel Bogumił (1771-1847), w: Polski Słownik Biograficzny, t. 17, Wrocław 1972.

J. Mrówczyński, http://www.biz.xcr.pl/files/Mrowczy-ski-SmolikowskiCR.pdf (7.03.2017).

W. Rukóyżo, Regulski Aleksander Tadeusz (1839-1884), w: Polski Słownik Biograficzny, t. 30, Wrocław 1987, s. 739.

J. Rostafiński, Odezwa do nie botaników o zbieranie ludowych nazw roślin (wyd. IV), mps, Kraków IX. 1883.

J. Rostafiński, Polska z czasów przedhistorycznych pod względem fizyograficznym i gospodarskim, rzecz czytana na publicznem posiedzeniu Akademii umiejętności w d. 21 maja 1887 r., "Rocznik Zarządu Akademii Umiejętności" 8 (1887), s. 113-153.

J. Rostafiński, Spis treści, rkps, 13 I 1888.

J. Rostafiński, Zielnik czarodziejski. To jest zbiór przesądów o roślinach, Kraków 1893, Katowice 2016.

S. Syreński, Zielnik Herbarzem z ięzyka Łacinskiego zowia. To iest Opisanie własne imion, kształtu, przyrodzenia, skutkow, y mocy Zioł wszelakich Drzew, Krzewin y korzenia ich, Kwiátu, Owocow, Sokow Miasg, Zywic y korzenia do potraw zaprawowania. Tak Trunkow, Syropow, Wodek, Likworzow, Konfitor, Win rozmaitych, Prochow, Soli z zioł czynioney; Maści, Plastrow. Przytym o Ziomach y Glinkach rożnych: o Kruscach Perłach y drogich Kamieniach. Tez o zwierzetach czworonogich, czołgajacych Ptastwie, Rybach y tych wszystkich rzeczach ktore od nich pochodza od DIOSCORIDA z przydaniem y dostatecznym dokładem $z$ wielu innich o tey materiey piszacych, z położeniem własnych figur dla snadnieyszego ich poznania a y używania ku zatrzymaniu zdrowia tak ludzkiego iako bydlecego y chorob przypadłych odpedzenia, z wielkiem uważaniem y rozsadkiem Polskiem iezykiem zebrany y na osmiero ksiag rozłożony, Kraków 1613. 
B. Tomiak , Michał Hórnik - duchowy orędownik polskości na Łużycach, "Nasze Historie" 1999 nr 4, s. 19-22.

Trzaski, Everta i Michalskiego Leksykon Ilustrowany, red. S. Lam, Kraków 1931.

S. Zamecki, Kazimierz Smoleński, „Przemysł Chemiczny" 75 (1996) nr 5, s. 189-190.

A. Zemanek, Koleje życia Józefa Rostafińskiego, w: Józef Rostafiński.

Botanik i humanista, red. A. Zemanek, Kraków 2000, s. 19-106. 


\section{Abstrakt}

Krzysztof Duda

Przyczynek do historii nauki i kultury polskiej, czyli o odnalezionych archiwaliach Józefa Rostafińskiego (1850-1928)

Józef Rostafiński w 1883 r. wystosował ankietę zwaną Odezwa, której celem było zbadanie tradycji używania roślin wśród ludu żyjącego na terytorium trzech zaborów Pierwszej Rzeczpospolitej. Rostafiński chciał dzięki temu uzyskać materiał źródłowy dotyczący zwyczajów stosowania ziół w kuchni, obrzędach i medycynie ludowej. Na podstawie uzyskanych danych wydawał publikacje naukowe. Archiwalne odpowiedzi na Odezwę Rostafińskiego w dużej części zostały zachowane w zbiorze Uniwersytetu Jagiellońskiego, natomiast część uznawano za zaginioną. W 2014 r. w dokumentach po prof. Tadeuszu Wilczyńskim ze Lwowa odnaleziono odpowiedzi związane z Odezwa oraz inne dokumenty, np. listy Pawła Smolikowskiego CR, Jana Karłowicza, które zasygnalizowano w artykule.

Słowa kluczowe: Józef Rostafiński, Odezwa, Tadeusz Wilczyński, Zielnik Czarodziejski, Paweł Smolikowski CR, Jan Karłowicz, Józefa Morawska. 


\title{
Abstract
}

\author{
Krzysztof Duda \\ A contribution to the history of Polish science and culture or on the recovered \\ archives of Józef Rostafiński (1850-1928)
}

Keywords:

Józef Rostafiński, Odezwa (Appeal),

Tadeusz

Wilczyński, Zielnik

Czarodziejski

(The Magic

Herbarium), Paweł

Smolikowski CR,

Jan Karłowicz,

Józefa Morawska.
In 1883, Józef Rostafiński launched a questionnaire, called the Appeal (Odezwa), the objective of which was to look into the tradition of using plants among the people living in the three territories of the First Polish Commonwealth annexed in the partitions. Thereby, Rostafiński wanted to obtain source material concerning the custoims related to the use of herbs in cooking, rituals and folk medicine. Based on the data obtained, he published scientific works. The archival responses to Rostafiński's Appeal were largely preserved in the collection of the Jagiellonian University. However, a portion was considered lost. In 2014, they were found among the documents left by Prof. Tadeusz Wilczyński of Lviv. Among the recovered archives of Rostafiński there are responses to the Appeal as well as other documents, e.g. letters by Paweł Smolikowski CR and Jan Karłowicz, which will be mentioned in the paper.

Folia Historica Cracoviensia, t. 23, z. 2 (2017) 